\title{
Pengaruh Penerapan Model Pembelajaran Koperatif Tipe Course Review Horay Terhadap Hasil Belajar Sejarah di SMK Negeri 31 Jakarta
}

\author{
Oleh : Eka Eviyanah, Umasih, Kurniawati \\ SMK Santa Lucia \\ Ekaeviyanah184@gmail.com
}

\begin{abstract}
This study aims to obtain empirical data of the impact of the application of course review horay type cooperative learning model to the learning result of history at SMK Negeri 31 Jakarta. This study was conducted from Juni 2017 to January 2018This study is a quantitative study with experimental method. The population target of this study was 16 classes contain 541 students. The reachable population is 10th graders covered five classes. The sample of this study is two classes, X OTP 2 (Otomatisasi Tata Kelola Perkantoran) and X AKL (Akuntansi dan Keuangan Lembaga) which defined through random sampling. The experiment class is X OTP 2 and the control clas is X AKL. Through the validity formula, " $r$ Product Moment", the result showed that from 60 instruments questions, 40 questions was valid and 20 questions is invalid. The readability test, with Spearman Brown. The normality test used Lilliefors. In the homogeneous test used Barlette. The hypothesis used $t$ formula with the trusted level 95\% $(a=0,05)$. So, it could be concluded that there was an impact of the use of the impact of the application of course review horay type cooperative learning model to the learning result of history at SMK Negeri 31 Jakarta.
\end{abstract}

Key words: result of historical learning, cooperative learning, course review horay

Abstrak: Penelitian ini bertujuan untuk mendapatkan data empiris tentang Pengaruh Penerapan Model Pembelajaran Kooperatif Tipe Course Review Horay Terhadap Hasil Belajar Sejarah di SMK Negeri 31 Jakarta. Penelitian ini berlangsung dari bulan Juni 2017 sampai Januari 2018.Pendekatan penelitian kuantitatif dengan metode eksperimen. Populasi target adalah seluruh siswa SMK Negeri 31 Jakarta, terdiri dari 16 kelas yang berjumlah 541 siswa. Populasi terjangkau penelitian ini adalah siswa Kelas X yang terbagi menjadi lima kelas. Sampel penelitian ini terdiri dari dua kelas dengan menggunakan teknik Simple Random sampling sehingga didapatkan kelas X OTP 2 (Otomatisasi Tata Kelola Perkantoran) sebagai kelas eksperimen dan kelas X AKL (Akuntansi dan Keuangan Lembaga) sebagai kelas kontrol. Melalui uji validitas dengan rumus "r Product Moment" hasilnya menunjukkan dari 60 soal instrumen 40 soal valid dan 20 soal tidak digunakan sedangkan uji reliabilitas dengan rumus Spearman Brown. Pengujian normalitas dengan menggunakan uji Lilliefors. Uji homogenitas menggunakan uji Bartlett Pengujian hipotesis menggunakan rumus uij t pada taraf kepercayaan 95\% ( $a=0,05)$. Sehingga dapat disimpulkan bahwa terdapat Pengaruh Penerapan Model Pembelajaran Kooperatif TipeCourse Review Horay Terhadap Hasil Belajar Sejarah di SMKNegeri31 Jakarta.

Kata Kunci: hasil belajar sejarah, pembelajaran kooperatif, model course review horay 


\section{PENDAHULUAN}

Pada Kurikulum 2013, guru dituntut berperan secara aktif sebagai motivator dan fasilitator pembelajaran sehingga siswa akan menjadi pusat belajar (Student Centered) tidak lagi berpusat pada guru (Teacher Centered). Pembelajaran dapat memberikan kesempatan kepada peserta didik untuk memiliki kemampuan menyerap ilmu pengetahuan, sistem berpikir, nilai dan moral serta keterampilan. Keberhasilan pembelajaran ditandai dengan kemampuan peserta didik mencapai tujuan pembelajaran atau kompetensi yang diharapkan. Dalam pembelajaran Kooperatif proses pembelajaran tidak harus belajar dari guru kepada siswa. Siswa dapat saling membelajarkan sesama siswa lainnya.

Slavin (2010:5) mengemukakan bahwa, “ hasil penelitian membuktikan bahwa penggunaan pembelajaran Kooperatif dapat meningkatkan prestasi belajar siswa sekaligus dapat meningkatkan kemampuan hubungan sosial, menumbuhkan sikap menerima kekurangan diri dan orang lain serta dapat meningkatkan harga diri. Pembelajaran Kooperatif dapat merealisasikan kebutuhan siswa dalam belajar berpikir memecahkan masalah dan mengintegrasikan pengetahuan dengan keterampilan.

Dalam Pembelajaran Kooperatif terdapat lima unsur yang harus diterapkan dalam Pembelajaran Kooperatif Roger dan David Johnson (Lie, 2014:31) mengemukakan bahwa, “Tidak semua kerja kelompok bisa dianggap Pembelajaran Kooperatif untuk mencapai hasil yang maksimal harus

menerapkan lima unsur model Pembelajaran Kooperatif seperti saling ketergantungan positif, tanggung jawab perseorangan, tatap muka, komunikasi antar anggota, evaluasi proses kelompok.

Course Review Horay adalah salah satu pembelajaran Pembelajaran 
Kooperatif yang bersifat menyenangkan dan meningkatkan kemampuan siswa dalam berkompetisi secara positif dalam pembelajaran, selain itu juga dapat mengembangkan kemampuan berpikir kritis siswa, serta membantu siswa untuk mengingat konsep yang dipelajari secara mudah. Model pembelajaran Course Review Horay ini juga merupakan suatu model pembelajaran yang dapat digunakan guru untuk mengubah suasana pembelajaran di dalam kelas dengan lebih menyenangkan, sehingga siswa merasa lebih tertarik. Model pembelajaran ini didesain untuk menguji pemahaman siswa dengan menggunakan strategi games, jika siswa mampu menjawab benar maka siswa akan berteriak 'horay'.

Kuntowijoyo (2013:17) mengemukakan, belajar sejarah adalah belajar mengenai peristiwa masa lalu beserta perubahannya, yang dimaksudkan agar siswa dapat meningkatkan pengetahuan tentang dunia sekitar tetapi juga dapat meningkatkan kemampuan berpikir kritis dari peristiwa masa lalu tersebut, mengambil hikmahnya untuk dijadikan pedoman sehingga diharapkan dapat menjadi manusia yang lebih bijaksana dalam kehidupan yang akan datang.

Hasan (2012:7) mengemukakan bahwa pendidikan sejarah di sekolah menengah tujuannya sudah berkembang mengarah kepada pemahaman secara mendalam berbagai peristiwa sejarah yang dianggap penting untuk membangun kemampuan berpikir, belajar, rasa ingin tahu, kepedulian sosial dan semangat kebangsaan. Sementara itu menurut Dimyati dan Mudjiono (2010:3-4) hasil belajar merupakan hasil dari suatu interaksi tindak belajar dan tindak mengajar, dari sisi guru, tindak mengajar diakhiri dengan proses evaluasi hasil belajar, dari sisi siswa. Jadi hasil belajar sejarah adalah perubahan yang terjadi dalam diri siswa serta penguasaan materi pelajaran 
setelah mengikuti proses pembelajaran sejarah dalam waktu tertentu.

Berdasarkan pemaparan di atas, peneliti tertarik untuk melakukan penelitian menggunakan model Course Review Horay terhadap hasil belajar sejarah, karena model Pembelajaran Kooperatif tipe Course Review Horay ini bersifat Student Centered, sesuai dengan tuntutan kurikulum 2013. Alasan peneliti memilih SMK Negeri 31 Jakarta adalah SMK Negeri 31 Jakarta sebagai sekolah menengah kejuruan dalam bidang bisnis dan manajemen yang sudah terakreditasi baik, namun dalam hasil belajar sejarah siswa nya masih jauh dari harapan. Berdasarkan hasil observasi di kelas $X$ banyak siswa yang tidak menyukai pelajaran sejarah dikarenakan pelajaran sejarah tidak dianggap penting untuk dipelajari dan tidak terlalu berpengaruh pada bidang keahlian bisnis dan manajemen. Padahal belajar sejarah mengajarkan siswa untuk berpikir kritis dan analitis yang dapat digunakan dalam melakukan perhitungan akuntansi, neraca pembayaran dan lain-lain.

Tujuan dari penelitian ini adalah untuk membuktikan ada tidaknya pengaruh penggunaan Model Pembelajaran Kooperatif tipe Course Review Horay Terhadap Hasil Belajar Sejarah Siswa di SMK Negeri 31 Jakarta.

\section{METODE}

Metode yang digunakan dalam penelitian ini adalah metode Kuantitatif dengan pendekatan Eksperimen. Dalam penelitian ini diberikan perlakuan terhadap dua kelompok yaitu kelompok eksperimen dan kelompok kontrol. Desain penelitian ini dengan menggunakan pre-test dan post-test yang menggunakan dua kelas yaitu pada kelompok eksperimen diberi penerapan model Pembelajaran Kooperatif tipe Course Review Horay, sedangkan kelompok kontrol tidak. Populasi target dalam penelitian ini adalah seluruh siswa di SMK Negeri 31 Jakarta yang berjumlah 541 siswa yang terdiri dari 16 
kelas, sedangkan populasi terjangkaunya adalah kelas X SMK Negeri 31 Jakarta yang berjumlah 175 siswa yang terdiri dari 5 kelas. Teknik pengambilan sampel dalam penelitian ini ditentukan dengan Simple Random Sampling. Sampel dalam penelitian ini yaitu kelas X OTP 2 sebagai kelas eksperimen dan kelas X AKL sebagai kelas kontrol masing-masing berjumlah 35 siswa.

\section{HASIL}

Berdasarkan data dari perhitungan variabel penelitian ini, yaitu hasil dari nilai test belajar kelas eksperimen dan kelas kontrol sebagai berikut:

Tabel 1. Deskripsi Data Penelitian

\begin{tabular}{ccc}
\hline Variabel & Kelas Eksperimen & Kelas Kontrol \\
\hline Nilai tertinggi & 47 & 28 \\
Nilai terendah & 20 & 5 \\
Rata-rata & 35,83 & 19,60 \\
Simpangan baku & 6,84 & 6,35 \\
\hline Varians & 46,73 & 40,31 \\
\hline
\end{tabular}

Berdasarkan tabel deskripsi data penelitian di atas memperlihatkan bahwa nilai tertinggi pada kelas eksperimen mencapai 47, sedangkan kelas kontrol mencapai 28. Nilai terendah kelas eksperimen 20, sedangkan kelas kontrol 5. Nilai rata-rata yang didapatkan kelas eksperimen 35,83, sedangkan kelas kontrol 19,60. Simpangan baku kelas eksperimen 6,84 dengan varians 46,73, sedangkan kelas kontrol 6,35 dengan varians 40,31. 
Tabel 2. Distribusi Hasil Belajar Kelas Eksperimen

\begin{tabular}{ccccc}
\hline $\begin{array}{c}\text { Kelas } \\
\text { Interval }\end{array}$ & Batas Bawah & Batas Atas & $\begin{array}{c}\text { Frek. } \\
\text { Absolut }\end{array}$ & $\begin{array}{c}\text { Frek. } \\
\text { Relatif }\end{array}$ \\
\hline $20-24$ & 19.5 & 24 & 9 & $25.0 \%$ \\
$25-30$ & 24.5 & 30.5 & 10 & $27.8 \%$ \\
$31-35$ & 30.5 & 35 & 5 & $13.9 \%$ \\
$36-40$ & 35.5 & 40 & 6 & $16.7 \%$ \\
$41-45$ & 40.5 & 45 & 3 & $8.3 \%$ \\
$46-50$ & 45.5 & 50 & 3 & $8.3 \%$ \\
\hline Jumlah & & & 36 & $100 \%$ \\
\hline
\end{tabular}

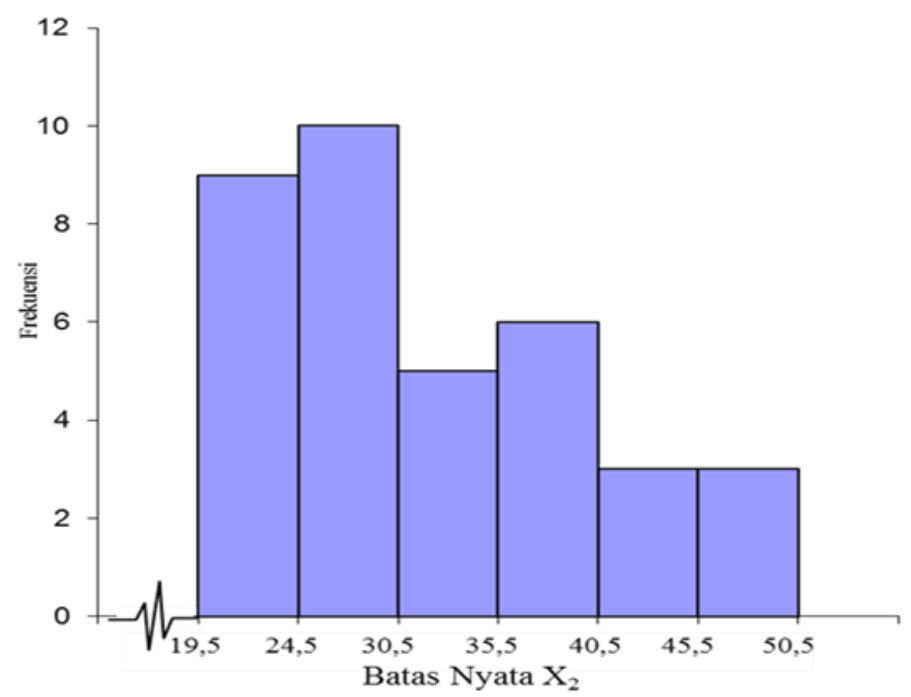

Grafik 1. Histogram Data Kelas Eksperimen

Berdasarkan tabel dan grafik tersebut di atas memperlihatkan bahwa frekuensi data tertinggi di kelas interval 25-30 yaitu sebesar 10. Frekuensi tersebut berada di titik tengah yaitu 28. Sedangkan data terendah pada kelas interval 41-45 dan 46-50 yaitu sebesar 3. Frekuensi tersebut berada di titik tengah yaitu 43,5 dan 47,5 . 
Tabel 3. Distribusi Hasil Belajar Kelas Kontrol

\begin{tabular}{|c|c|c|c|c|c|}
\hline \multicolumn{2}{|c|}{$\begin{array}{c}\text { Kelas } \\
\text { Interval }\end{array}$} & Batas Bawah & Batas Atas & $\begin{array}{c}\text { Frek. } \\
\text { Absolut }\end{array}$ & Frek. Relatif \\
\hline & & & & 0 & \\
\hline 5 & -8 & 4.5 & 8.5 & 7 & $19.4 \%$ \\
\hline 9 & - 1 & 8.5 & 12.5 & 5 & $13.9 \%$ \\
\hline 13 & -1 & 12.5 & 16.5 & 6 & $16.7 \%$ \\
\hline 17 & -2 & 16.5 & 20.5 & 7 & $19.4 \%$ \\
\hline 21 & -2 & 20.5 & 24.5 & 4 & $11.1 \%$ \\
\hline \multirow[t]{2}{*}{25} & -2 & 24.5 & 28.5 & 7 & $19.4 \%$ \\
\hline & & & & 0 & \\
\hline \multicolumn{2}{|c|}{ Jumlah } & & & 36 & $100 \%$ \\
\hline
\end{tabular}

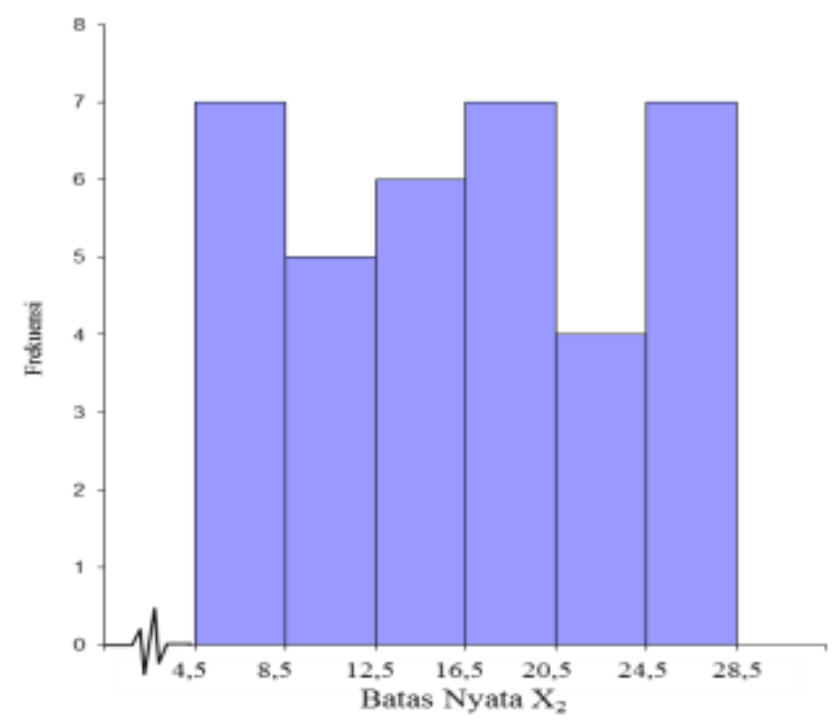

Grafik 2. Grafik Histogram Data Kelas Kontrol

Berdasarkan tabel dan grafik tersebut di atas memperlihatkan bahwa frekuensi data tertinggi di kelas interval 5-8, 17-20 dan 25-28 yaitu sebesar 7. Frekuensi tersebut berada di titik tengah yaitu $(6,5),(18,5)$, dan $(26,5)$. Sedangkan data terendah pada kelas interval 21-24 yaitu sebesar 4 . Frekuensi tersebut berada di titik tengah 22,5. 
Berdasarkan uji normalitas pada data yang berasal dari kelas eksperimen diperoleh Lhitung $<$ Ltabel yaitu 0,091 < 0,148 pada taraf kepercayaan 95\% $(a=0,05)$ dan jumlah sampel 35, maka H0: sebaran data kelas eksperimen normal di terima. Data yang berasal dari kelas kontrol diperoleh Lhitung<Ltabel yaitu 0,145 < 0,148 pada taraf kepercayaan 95\% $(a=0,05)$ dan jumlah sampel 35 maka H0: sebaran data kelas kontrol normal diterima. Dapat disimpulkan bahwa sampel kelas eksperimen dan kelas kontrol berdistribusi normal.

Berdasarkan perhitungan, maka pada data pre-test dan post-test diperoleh $\mathrm{x} 2$ (hitung) $<\mathrm{x} 2$ (tabel) pada taraf kepercayaan $95 \%(\alpha=0,05)$ dan derajat kebebasan $=1$ yaitu $0,186<3,84$. Maka hipotesis $\mathrm{H} 0: \sigma 1=\sigma 2$ atau data berasal dari populasi yang memiliki varians homogen diterima. Kesimpulannya bahwa data hasil belajar kelas eksperimen OTP 2 dan kelas kontrol AKL berasal dari populasi yang sama atau homogen karena mempunyai varians yang sama.

Melalui teknik analisis data statistik yaitu diperoleh thitung $=10,687$ sedangkan ttabel 2,00 pada taraf kepercayaan $95 \%(\alpha=0,05)$ dengan derajat kebebasan $=68$. Hal ini menunjukan bahwa thitung $>$ ttabel maka H0 ditolak dan $\mathrm{H} 1$ diterima atau dengan kata lain terdapat pengaruh model Pembelajaran Kooperatif tipe Course Review Horay terhadap hasil belajar sejarah.

\section{PEMBAHASAN}

Berdasarkan hasil perhitungan statistik yang telah dilakukan dapat diketahui bahwa terdapat pengaruh antara penerapan model Pembelajaran Kooperatif tipe Course Review Horay terhadap hasil belajar sejarah siswa kelas X SMK Negeri 31 Jakarta. Hal ini didasarkan pada rata-rata selisih 
hasil belajar sejarah siswa kelas eksperimen sebesar 35,80 lebih besar dari rata-rata selisih hasil belajar sejarah siswa kelas kontrol sebesar 19,60. Setelah diuji dengan menggunakan statistik uji-t taraf signifikan 95\% ( $\alpha=$ 0,05 ) diperoleh harga thitung sebesar 10,687 artinya lebih besar dari harga ttabel sebesar 2,00 pada derajat kebebasan yaitu 68. Karena harga thitung lebih besar dari harga ttabel, sehingga H0 ditolak dan H1 diterima maka diperoleh kesimpulan bahwa terdapat pengaruh penerapan Pembelajaran Kooperatif tipe Course Review Horay terhadap hasil belajar sejarah pada siswa kelas X di SMK Negeri 31 Jakarta.

Keterbatasan dalam penelitian ini yaitu 1) Penerapan model Pembelajaran Kooperatif tipe Course Review Horay ini menuntut siswa untuk membuat yel-yel terlebih dahulu sehingga membutuhkan waktu untuk memikirkan yel-yel yang akan digunakan masing-masing kelompok. 2) Suasana kelas dengan model Pembelajaran Kooperatif tipe Course Review Horay ini cenderung berisik karena setiap kelompok yang menang akan membunyikan yel-yel kelompoknya, ruangan kelas yang tidak kedap suara membuat kelas berisik dan mengganggu kelas yang lain.

Maka hal ini berimplikasi bahwa Model Pembelajaran Kooperatif Tipe Course Review Horay dapat meningkatkan hasil belajar sejarah siswa, serta dapat membantu siswa dalam hal menerima materi pelajaran sejarah dengan lebih baik, model pembelajaran ini dapat menciptakan suasana kelas menjadi meriah dan menyenangkan karena setiap kelompok yang dapat menjawab benar maka siswa tersebut diwajibkan berteriak "HORAY" atau yel-yel lainnya yang disukai. Selain itu, model pembelajaran ini mampu mendorong siswa untuk ikut berperan aktif dalam pembelajaran sejarah. 


\section{PENUTUP}

Hasil belajar sejarah siswa sebelum diberikan Treatment, hasil belajarnya sangat rendah jika mengacu kepada nilai ketuntasan Kriteria Ketuntasan Minimal (KKM) yaitu 75. Berdasarkan hasil perhitungan menunjukan bahwa skor rata-rata selisih nilai pre test dan post test kelas eksperimen sebesar 35,80 lebih besar dibandingkan dengan skor rata-rata selisih nilai pre test dan post test kelas kontrol sebesar 19,60. Melalui teknik analisis data statistik yaitu diperoleh thitung $=10,687$ sedangkan ttabel 2,00 pada taraf kepercayaan $95 \%(\alpha=0,05)$. Hal itu menunjukan bahwa thitung $>$ ttabel maka H0 ditolak dan H1 diterima atau dengan kata lain terdapat pengaruh penerapan Model Pembelajaran Kooperatif Tipe Course Review Horay terhadap hasil belajar sejarah.

Model pembelajaran Course Review Horay diharapkan dapat melatih kerja sama dalam menyelesaikan masalah dengan pembentukan kelompok, pembelajarannya menarik dan mendorong siswa untuk terjun kedalamnya, tidak monoton karena diselingi sedikit hiburan sehingga suasana tidak menegangkan serta siswa lebih semangat belajar karena suasana pembelajaran berlangsung menyenangkan sehingga mampu membantu siswa dalam meraih nilai yang tinggi. Oleh karena itu pelaksanaannya perlu mendapat perhatian dari pihak guru maupun sekolah. Bagi guru sejarah, model pembelajaran ini dapat membantu guru dalam hal penyajian materi kepada siswa sehingga siswa lebih siap menerima materi pelajaran baik secara individu maupun kelompok. 


\section{DAFTAR PUSTAKA}

[1] Dimyati dan Mudjiono. (2010). Belajar dan Pembelajaran. Jakarta: Rineka Cipta.

[2] Hasan, Hamid. (2012). Pendidikan Sejarah Indonesia. Bandung: Rizqi Press.

[3] Kuntowijoyo. (2013). Pengantar Ilmu Sejarah. Yogyakarta: Tiara Wacana.

[3] Lie, Anita. (2014). Cooperative Learning. Jakarta: Gramedia.

[4] Slavin, Robert E. (2010). Cooperative Learning: Teori, Riset, dan Praktik. Bandung: Nusa Media. 